\title{
Peran Sistem Tata Udara dalam Pencegahan dan Pengendalian Infeksi Di Ruang Isolasi Airborne RSPI Prof. Dr. Sulianti Saroso Tahun 2017
}

\author{
The Role of Air Regulating Systems in Prevention and Control of Infection at \\ Airborne Isolation Room of RSPI Prof. Dr. Sulianti Saroso in 2017
}

\author{
Titi Sundari ${ }^{*}$, Vivi Lisdawati, Jahiroh, Ehwan Zunaidi, Deki Indrawanto, Farida Murtiani, \\ Yohana, Maya Marinda Montain, Temmasonge Radi Pakki, Rita Rogayah
}

RSPI Prof. Dr. Sulianti Saroso, Kementerian Kesehatan Republik Indonesia

*Korespondensi Penulis :

Titi Sundari

Email : tt_sundari@yahoo.com

\begin{abstract}
Abstrak
Latar belakang : Sistem tata udara di ruang isolasi dirancang untuk mengurangi/menghilangkan penyebaran agen infeksius dengan cara menciptakan ruangan yang bertekanan negatif dan pergantian udara $\geq 12$ Air Change per Hour $(\mathrm{ACH})$ serta menggunakan hepafilter. Studi ini bertujuan menilai sistem tata udara ruang isolasi RSPI Prof. Dr. Sulianti Saroso dalam rangka pencegahan dan pengendalian infeksi yang disebabkan oleh airborne diseases. Metode : Studi cross sectional menggunakan data hasil pengukuran volume dan pergantian udara pada 11 kamar isolasi. Pengukuran dilakukan sebanyak dua kali yaitu pada awal dan setelah waktu pemeliharaan berkala. Data dianalisis mengacu pada standar nasional dan internasional. Hasil : Data volume udara pada pengukuran I, dikoridor: 585,89 $\mathrm{M}^{3}$; anteroom I-XI : $8,52 \mathrm{~s} / \mathrm{d}$ 49,07 $\mathrm{M}^{3}$; kamar pasien I-XI: 0,1 s/d 11,65 $\mathrm{M}^{3}$; toilet -214,55 s/d -10,29 $\mathrm{M}^{3}$. Data pengukuran II, volume udara dikoridor: $259,32 \mathrm{M}^{3}$; anteroom I-XI : 4,53 s/d 18,13 $\mathrm{M}^{3}$; kamar pasien I-XI: 0,24 s/d 11,65 $\mathrm{M}^{3}$; toilet $-69,15 \mathrm{~s} / \mathrm{d}-30,11 \mathrm{M}^{3}$. Aliran udara mengalir dari ruang dengan volume tinggi menuju ke ruang dengan volume lebih rendah. Data pergantian udara pada pengukuran I, kamar pasien I-XI: 6,2 s/d 12,8 $\mathrm{ACH}$. Data pengukuran II, kamar pasien I-XI: 12,11 s/d 12,99 ACH. Pengendalian infeksi semakin efektif dengan pergantian udara $\geq 12 \mathrm{ACH}$. Kesimpulan : Sistem tata udara berperan penting dalam pencegahan dan pengendalian infeksi di ruang isolasi airborne. Hal ini perlu ditunjang dengan pemeliharaan dan pemeriksaan berkala agar besaran volume, pertukaran dan aliran udara sesuai standar.
\end{abstract}

Kata kunci : sistem tata udara, isolasi airborne, pengendalian infeksi

\begin{abstract}
Background : The air system in the isolation room is designed to reduce/eliminate the spread of infectious agents by creating a negative pressure room and air change $\geq 12$ Air Change per Hour $(A C H)$ and using a hepafilter. This study aims to assess the mechanism of the $R \overline{S P I}$ isolation room air system Prof Dr. Sulianti Saroso in order to prevent and control infections caused by airborne diseases. Method : A cross-sectional study using data on the measurement of volume and turnover of air in 11 isolation rooms. Measurements are made twice namely at the beginning and after the period of regular maintenance. Data analyzed refers to national and international standards. Results: Data on air volume in measurement I, corridor: 585.89 M3; antheroom I-XI: -8.52 to 49.07 M3; I-XI patient room: 0.1 to $11.65 \mathrm{M3}$; toilet -214.55 to -10.29 M3. Measurement data II, air volume in corridor: $259.32 \mathrm{M3}$; antheroom I-XI: 4.53 to $18.13 \mathrm{M3}$; I-XI patient room: 0.24 to $11.65 \mathrm{M3}$; toilet -69.15 to $-30.11 \mathrm{M}$. Air flow flows from high-volume space to a lower volume space. Air change data in measurement I, patient room I-XI: 6.2 to $12.8 \mathrm{ACH}$. Measurement data II, patient room I-XI: 12.11 to $12.99 \mathrm{ACH}$. Infection control is more effective with air change> $12 \mathrm{ACH}$. Conclusion : Air handling sistem an important role in the prevention and control of infections in airborne isolation spaces. This needs to be supported by periodic maintenance and inspection so that the volume, exchange and airflow amounts are according to the standard.
\end{abstract}

Keywords: air system, airborne isolation, infection control 


\section{Pendahuluan}

RSPI Prof. Dr. Sulianti Saroso (RSPISS) sebagai pusat kajian dan rujukan nasional penyakit infeksi serta sebagai salah satu rumah sakit rujukan penanggulangan Flu Burung (Avian Influenza), mempunyai 11 ruang isolasi airborne (terdiri dari 10 kamar perawatan pasien dan 1 kamar HCU), yang digunakan untuk merawat pasien dengan Penyakit Infeksi New Emerging dan Re-Emerging (PINERE), baik yang ditransmisikan secara airborne atau yang belum jelas diketahui transmisinya. $^{(1,2)}$ Pasien PINERE tersebut merupakan sumber utama kuman patogen yang dikeluarkan pada saat pasien batuk, berbicara, bersin, atau meludah. Untuk mencegah transmisi mikroorganisme dari pasien ke pasien lain, ke petugas, ke pengunjung dan lingkungan, maka sistem isolasi

yang diterapkan adalah isolasi airborne. ${ }^{(3-5)}$

Sistem tata udara yang terpasang di ruang isolasi airborne RSPI-SS dirancang sesuai standar nasional maupun internasional, yaitu ruangan bertekanan negatifdan mempunyai pergantian udara $\geq 12$ Air Change per Hour (ACH) serta dilengkapi hepafilter. ${ }^{(4-9)}$ Sangat penting mengupayakan ruang bertekanan negatif dikamar isolasi airborne. Perbedaan tekanan antar kamar pasien dengan ruang anteroom dan koridor harus direncanakan dengan benar untuk mencegah adanya migrasi sumber infeksi dari kamar pasien menuju ke anteroom dan koridor. Pergantian udara per jam juga diperlukan untuk mencegah penularan infeksi yang

ditransmisikan melalui udara. Pergantian udara yang tinggi $(\geq 12 \mathrm{ACH})$ dapat mempercepat dilusi pathogen dan

mengurangi risiko infeksi yang ditransmisikan melalui udara. Sistem filterasi berfungsi untuk menyaring udara dari partikel yang berukuran $1-5$ mikron, sehingga udara yang menuju ruangan merupakan udara yang bersih dari kuman pathogen. ${ }^{(5)}$

Bila di ruang isolasi airborne tidak ada tekanan negatif, dan pergantian udara kurang dari $12 \mathrm{ACH}$ serta tidak ada filterasi, maka aliran udara patogen dari kamar pasien akan mengalir ke berbagai arah, baik ke dalam maupun ke luar kamar pasien, sehingga udara patogen tersebut kemungkinan dapat terhirup dan menginfeksi petugas, pasien lain atau pengunjung rumah sakit. ${ }^{(10)}$ Bila petugas terinfeksi kuman patogen tersebut, mereka bisa menjadi sumber penularan ke petugas lain, ke pasien, dan ke anggota keluarganya.

Hal ini dapat mengakibatkan kemungkinan terjadinya outbreak (KLB) penyakit infeksi yang meluas baik dilingkungan rumah sakit maupun 
lingkungan tempat tinggal petugas tersebut. ${ }^{(6)}$

Sistem tata udara di ruang isolasi airborne RSPI Prof. Dr. Sulianti Saroso telah terpasang tahun 2011, dan sampai dengan saat ini $( \pm 6$ tahun) belum pernah dilakukan pengukuran terhadap sistem tata udara di ruang isolasi airborne. Oleh karena itu, untuk mengetahui fungsi sistem tata udara di ruang isolasi RSPI-SS berjalan dengan baik sesuai dengan parameter/standar, maka perlu dilakukan kajian tentang peran sistem tata udara / AHU (Air Handling Unit), yang bertujuan untuk memastikan laik dan handalnya sistem tata udara suatu ruang isolasi, sehingga memberikan jaminan keamanan bagi petugas dan lingkungan.

\section{Metode}

Desain studi cross sectional, menggunakan data sekunder yaitu hasil pengukuran volume udara dan pergantian udara pada 11 kamar isolasi yang digunakan untuk merawat pasien infeksi yang ditransmisikan secara airborne atau yang belum jelas diketahui transmisinya. Kamar-kamar isolasi tersebut letaknya saling berhadapan dan dipisahkan oleh koridor. Kamar I-VI berada disebelah kanan sedangkan kamar VII-X dan ruang HCU berada disebelah kiri. Masing-masing kamar pasien dilengkapi dengan ruang anteroom dan toilet.

Pengukuran volume udara dan pergantian udara dilakukan sebanyak dua kali. Pengukuran I (pengukuran awal) yaitu pada September 2017 dan pengukuran II pada April 2018 (setelah dilakukan tindakan perbaikan sistem tata udara). Alat yang digunakan untuk mengukur aliran udara dan pergantian udara yaitu balometer. Data hasil pengukuran kemudian dianalisis secara deskriptif dan dikomparasi sesuai standard nasional dan standar internasional. Studi ini telah mendapatkan persetujuan etik dari KEPK RSPI Prof. Dr. Sulianti Saroso dengan Nomor 34/VII.10/VII/2017.

Volume udara adalah akumulasi udara yang berada dalam ruangan setelah memperhitungkan aliran udara masuk melalui FAD (Fresh Air Diffuser) dan keluar melalui EAG (Exhaust Air Grille) berbanding dengan luas ruangan. Semakin besar volume udara maka semakin positif tekanan pada ruangan tersebut. Apabila volume udara bernilai positif, maka hal ini berarti lebih banyak pasokan udara dibandingkan dengan pembuangan udaranya, demikian juga sebaliknya. Dengan membandingkan nilai tersebut pada masing-masing area/ruangan maka dapat diketahui arah aliran udara. Aliran udara mengalir dari 
ruang dengan volume tinggi menuju ke ruang dengan volume lebih rendah. ${ }^{(11)}$

\section{Hasil}

Pada pengukuran I, volume udara dikoridor sebesar 259,32 $\mathrm{M}^{3}$. Volumeudara di anteroom I-XI sebesar 8,52 s/d 49,07 $\mathrm{M}^{3}$. Volume udara di kamar pasien I-XI sebesar 0,10 s/d $11,65 \mathrm{M}^{3}$. Volume udara di toilet kamar IXI sebesar -214,55 s/d -10,29 $\mathrm{M}^{3} .100 \%$ volume udara di koridor lebih tinggi dibanding dengan anteroom, kamar pasien dan toilet. Arah aliran udara dari koridor semuanya menuju ke anteroom, kamar pasien dan toilet. Sebanyak 7 dari 11 kamar pasien (63\%) mempunyai volume udara yang lebih tinggi dibanding anteroom dan toilet. Arah aliran udara dari kamar pasien sebagian menuju anteroom dan sebagian lagi menuju toilet.

Data pengukuran II (setelah dilakukan tindakan perbaikan sistem tata udara) menunjukkan besaran volume udara: dikoridor (259,32 $\mathrm{M}^{3}$; anteroom I-XI : 4,53 s/d 18,13 $\mathrm{M}^{3}$; kamar pasien IXI: 0,24 s/d 11,65 M3 ; toilet - 69,15 s/d $30,11 \mathrm{M}^{3}$. Volume udara di koridor, anteroom, kamar pasien, dan toilet dari kamar I-XI sudah sesuai standar, dimana volume udara dikoridor $>$ anteroom > kamar pasien > toilet. Arah aliran udara dari koridor menuju ke anteroom, dari anteroom menuju ke kamar pasien, dan dari kamar pasien menuju ke toilet. (Tabel 1) (Gambar 1)

Tabel 1. Besaran Volume Udara pada Pengukuran I dan Pengukuran II di Ruang Isolasi, RSPI-SS

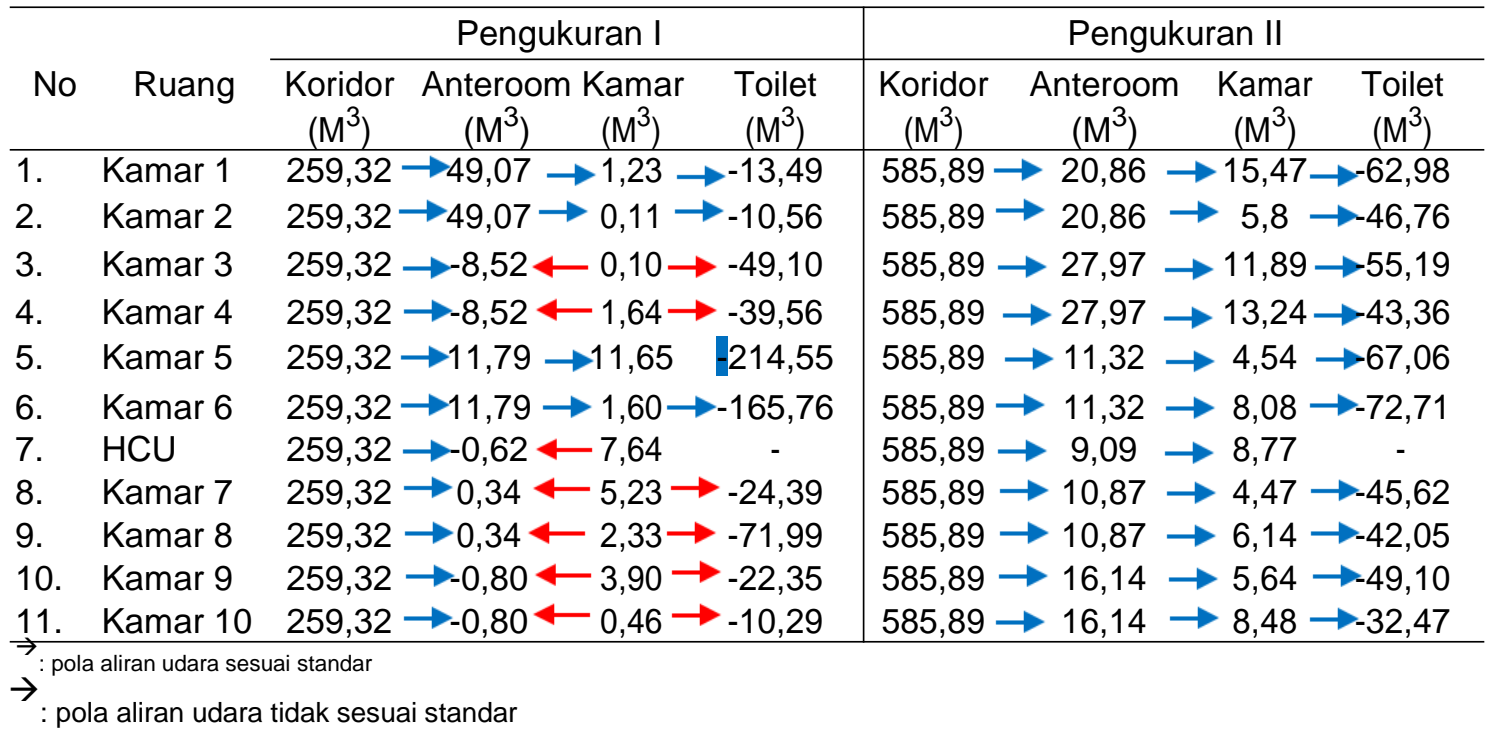




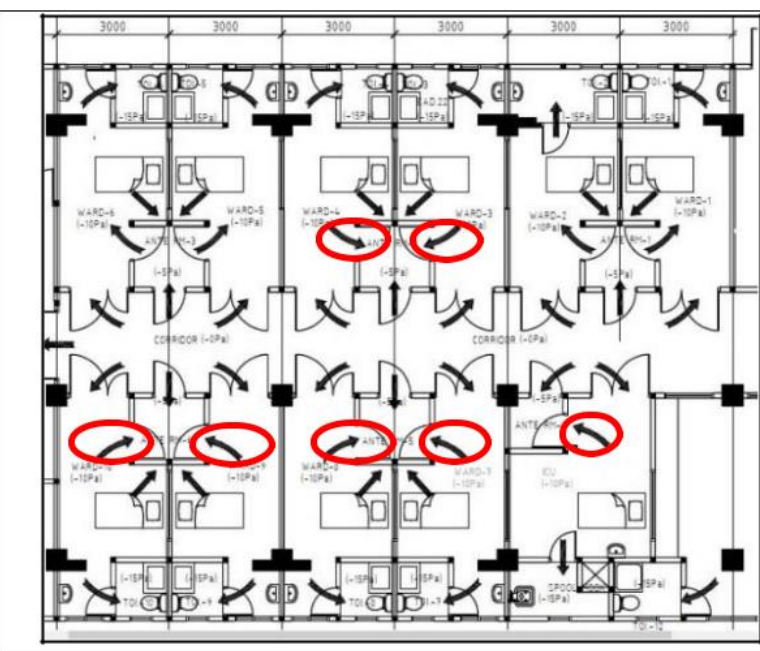

O : arah aliran udara tidak sesuai standar

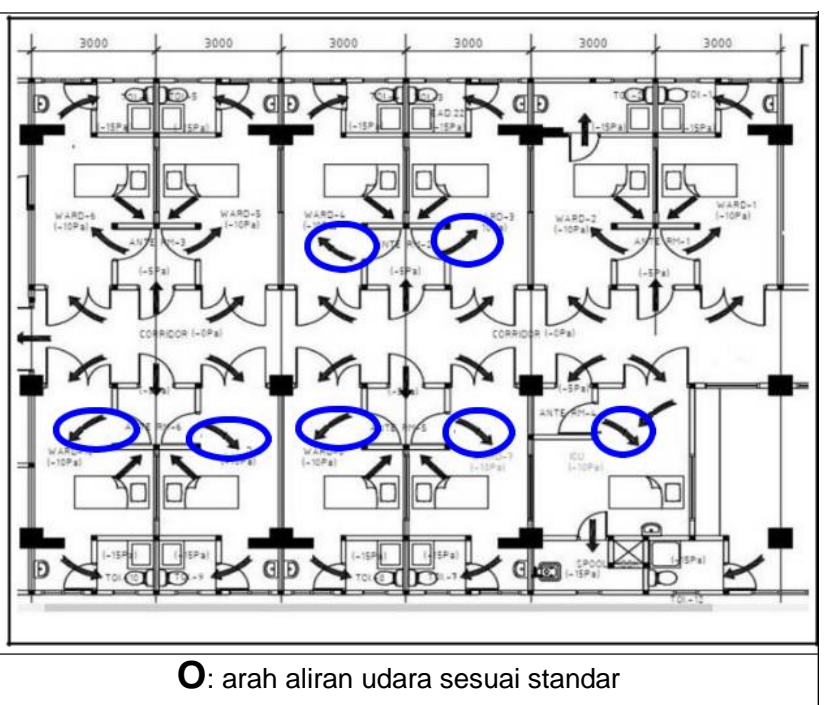

O: arah aliran udara sesuai standar

Gambar 1. Pola aliran udara pada pengukuran I dan pnegukuran II di Ruang Isolasi, RSPI-SS

Pada pengukuran I, sebanyak satu kamar $(9,1 \%)$ mempunyai pergantian udara dengan nilai 12,8 ACH. Namun, sebanyak 10 kamar $(90,9 \%)$ mempunyai pergantian udara $<12 \mathrm{ACH}$ dengan nilai 6,2 s/d 11,9 ACH. Pada pengukuran II, besaran pergantian udara di seluruh kamar pasien sudah memenuhi standar dengan nilai antara $12,03 \mathrm{~s} / \mathrm{d} \quad 12,78$ ACH. (Gambar 2)

Data suhu kamar I-XI pada pengukuran I dan II sudah sesuai standar, berkisar antara $20^{\circ} \mathrm{C}-25^{\circ} \mathrm{C}$. Demikian juga data kelembaban kamar I-XI sudah sesuai standar baik pada pengukuran I maupun pengukuran || dengan nilai antara 50\%-60\%.

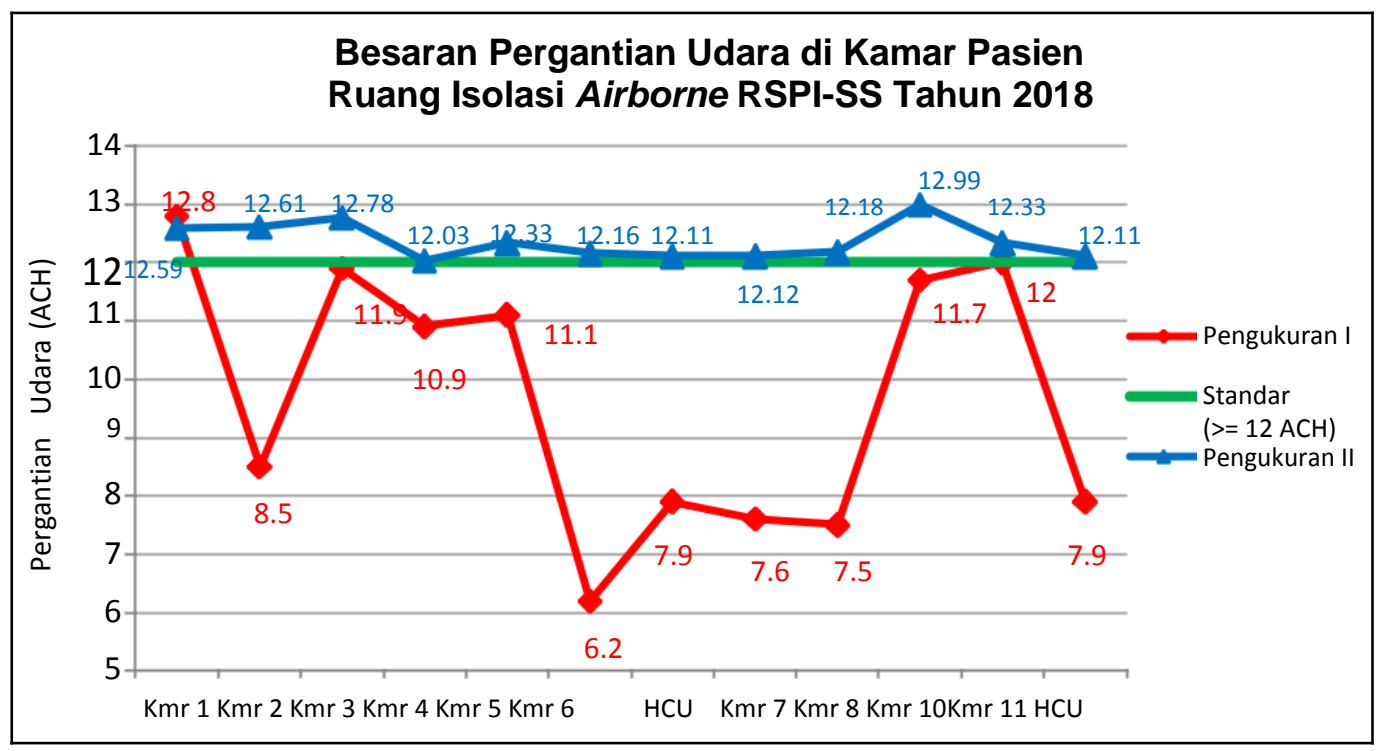

Gambar 2. Besaran Pergantian Udara di Kamar Pasien Ruang Isolasi Airborne 
Pembahasan

Pencegahan dan pengendalian infeksi khususnya penyebaran infeksi melalui udara (airborne infection) dapat dilakukan melalui pengendalian lingkungan (Engineering Enviromental Control dengan cara mengatur kecepatanaliran udara, jumlah dan

kualitas udara sehingga dapat menurunkan konsentrasi pathogen yang diharapkan dapat menurunkan infeksi. Pengendalian lingkungan bertujuan untuk menurunkan konsentrasi droplet nuklei atau partikel (termasuk kuman) dengan ukuran $<5 \mu \mathrm{m}$ yang bisa melayang diudara dan terhisap oleh

sistem pernafasan manusia. ${ }^{(4)(5)}$ Kementerian Kesehatan RI dan

American Society of Heating, Refrigeration, and AC Engineer

(ASHRAE), WHO serta CDC merekomendasikan untuk ruang isolasi airborne menggunakan ruangan yang bertekanan negatif dan mempunyai pergantian udara $\geq 12 \mathrm{ACH}$ serta menggunakan hepafilter. ${ }^{(3-9)(12)}$

Sistem tata udara diruang isolasi airborne RSPI Prof. Dr. Sulianti Saroso mempunyai komponen satu unit F-AHU (Fresh Air Handling Unit), 11 unit R-AHU (Re-circulation Air Handling Unit) dan exhaust fan, yang dilengkapi dengan media filter (pre, medium, hepafilter) dan sinar ultraviolet. Unit F-AHU memasok udara segar ke seluruh ruangan, sisanya diresirkulasi oleh R-AHU pada masing-masing ruang perawatan. Udarayang diresirkulasi ini akan melalui media filter (pre, medium, hepa) dan sinar ultraviolet, sehingga kualitas udara dalam ruanganbebas dari bakteri dan virus.

Pada studi ini, hasil pengukuran I (pengukuran awal) menunjukkan tekanan udara pada sebagian kamar pasien belum memenuhi standar, dimana tekanan udara dikamar pasien lebih tinggi (lebih positif) dibandingkan dengan anteroom dan toilet. Hal ini menyebabkan udara di kamar pasien tersebut, sebagian ada yang mengalir menuju ke anteroom dan sebagian lagi mengalir menuju toilet. Masuknya udara patogen dari kamar pasien ke anteroom, sangat berisiko bagi petugas kesehatan. Udara patogen tersebut dapat terhirup oleh petugassaat sedang berada di ruang anteroom. Bila petugas terinfeksi kuman pathogen, mereka bisa menjadi sumber penularan bagi petugas lain, pasien-pasien lain, dan anggota keluarganya, sehingga dapat mengakibatkan kemungkinan terjadinya outbreak(KLB) penyakit infeksi yang meluas baik dilingkungan rumah sakit maupun lingkungan tempat tinggal petugas tersebut. $^{(6)}$ 
Hasil pengukuran I, langsung ditindaklanjuti untuk perbaikan sistem tata udara oleh IPSRS bekerjasama dengan pihak ke III. Setelah dilakukan perbaikan pada sistem tata udara di ruang isolasi airborne RSPI-SS, besaran tekanan udara dan pergantian udara seluruh kamar pasien (kamar I-XI) sudah sesuai standar, sehingga dapat memberikan jaminan keamanan bagi petugas kesehatan dan lingkungan RSPI-SS. Pemeliharaan dan pemeriksaan terhadap sistem tata udara sangat penting dilakukan secara berkala, agar kualitas udara dalam ruangan tetap memenuhi persyaratan teknis dan kesehatan.

Pergantian udara per jam $(\mathrm{ACH})$ merupakanfrekuensi(berapa kali) udara dalam satu ruangan akan berganti dalam satu jam. Pergantian udara per jam diperlukan untuk membantu mencegah penularan patogen infeksius yang ditransmisikan melalui udara. Sistem ventilasi yang baik akan menjamin terjadinya pergantian udara di dalam gedung maupun luar gedung yang memadai, yang dapat menurunkan konsentrasi droplet nuklei sehingga dapat mengurangi risiko infeksi. Semakin besar pergantian udara maka akan semakin baik kualitas udara ruangan. ${ }^{(3)(6)}$

Unit tata udara sebagai prasarana dirumah sakit harus memenuhi standar pelayanan, keamanan, serta keselamatan dan kesehatan kerja penyelenggaraan rumah sakit dan harus dalam keadaan terpelihara dan berfungsi dengan baik. Pengoperasian dan pemeliharaan prasarana rumah sakit juga harus didokumentasikan dan dievaluasi secara berkala serta harus dilakukan oleh petugas yang mempunyai kompetensi di bidangnya. ${ }^{(13)}$

Pemeliharaan terhadap seluruh fasilitas yang menunjang pelayanan kesehatan di rumah sakit (sarana, prasarana dan peralatan) menjadi tanggung jawab IPSRS.

Pada studi ini, pengukuran terhadap sistem tata udara di ruang isolasi airborne RSPI-SS dilakukan setelah \pm 6 tahun sistem tata udara terpasang,

sehingga kemungkinan penyebab sistem tata udara tersebut mengalami penurunan performa dikarenakan telah terjadi perubahan/pergeseran parameter pada sistem ventilasi dantata udaranya, serta adanya pengaruh faktor-faktor eksternal yang menyebabkan peralatan dan instrumen elektronika mengalami perubahan.

Studi ini dapat digunakan sebagai studi awal untuk melakukan studi lanjutan tentang efektifitas sistem tata udara di ruang isolasi airborne berdasarkan frekuensi penggunaan kamar isolasi dalam merawat pasien airborne disease, yang bertujuan 
mengetahui periode waktu yang tepat dalam melakukan pengujian dan pemeriksaan sistem tata udara di ruang isolasi airborne.

\section{Kesimpulan}

Sistem tata udara berperan penting dalam pencegahan dan pengendalian infeksi di ruang isolasi airborne. Hal ini perlu ditunjang dengan pemeliharaan dan pemeriksaan berkala agar besaran volume, pertukaran dan aliran udara sesuai standar. Sistem tata udara di ruang isolasi airbone RSPI Prof. Dr. Sulianti Saroso membuktikan hasil yang baik setelah dilakukan pemeliharaan dan perbaikan sistem tata udara, yaitu besaran volume udara, pertukaran udara dan aliran udara sudah sesuai standar.

\section{Saran}

Pemeliharaan sistem tata udara di ruang isolasi perlu dilakukan pemeliharaan dan pemeriksaan secara berkala, terencana dan terjadwal, untuk meningkatkan perfoma peralatan sistem tata udara dan mencegah kerusakan yang lebih besar serta meningkatkan life time dari suatu peralatan sistem tata udara di suatu ruangan.

Apabila hasil pengukuran sistem tata udara di ruang isolasi airborne belum memenuhi standar, maka untuk memberikan jaminan keamanan bagi petugas kesehatan perlu dilakukan perubahan SPO pelepasan APD di anteroom.

\section{Ucapan Terima Kasih}

Penulis mengucapkan terima kasih kepada Direktur Utama beserta seluruh jajaran Direksi RSPI-SS atas izin dan dukungan yang diberikan kepada tim kajian dan juga kepada semua pihak yang berkonstribusi dalam kajian ini.

\section{Daftar Pustaka}

1. Keputusan Menteri Kesehatan Republik Indonesia Nomor 1138/Menkes/SK/X/2009 tentang penetapan RSPI Prof. Dr. Sulianti Saroso sebagai Pusat Kajian dan Rujukan Nasional Penyakit Infeksi.

2. Keputusan Menteri Kesehatan Republik Indonesia Nomor 414/Menkes/SK/IV/2007 tentang Penetapan Rumah Sakit Rujukan Penanggulangan Flu Burung (Avian Influenza). 2007.

3. Kementerian Kesehatan RI. Peraturan Menteri Kesehatan Nomor 27 Tahun 2017 tentang Pedoman Pencegahan Dan Pengendalian Infeksi Di Fasilitas Pelayanan Kesehatan. 2017;1172.Availablefrom: 
http://hukor.kemkes.go.id/uploads /produk_hukum/PMK_No._27_ttg _Pedoman_Pencegahan_dan_Pe ngendalian_Infeksi_di_FASYANK ES_pdf

4. WHO. Pencegahan dan

Pengendalian Infeksi Saluran Pernapasan Akut ( ISPA ) yang Cenderung Menjadi Epidemi dan Pandemi di Fasilitas Pelayanan Kesehatan. 2007; Available from: http://apps.who.int/iris/bitstream/1 0665/69707/14/WHO_CDS_EPR _2007.6_ind.pdf

5. Kementerian Kesehatan Republik Indonesia. Pedoman Teknis

Bangunan dan Prasarana Fasilitas Pelayanan Kesehatan

TingkatPertamaUntuk

Mencegah Infeksi Yang

Ditransmisikan Melalui Udara (Airborne Infection) [Internet].

2014. Available from: http://cwmbc.co.id/reportc3/2014/

Doc. 3.1.2-KSDA-TR-2014 Pedoman Teknis Pengembangan PES Jasling Air.pdf

6. Pedoman Tatalaksana Klinis Flu Burung ( H5N1 ) di Rumah Sakit. Keputusan Menteri Kesehatan Republik Indonesia No.933/Menkes/SK/VII/2010.

7. ASHRAE (American Society of Heating, Refirgeration and $A E$ ). Design Manual for Hospitals and
Clinics. 2013.

8. CDC. Guidelines for preventing the transmission of Mycobacterium tuberculosis in health-care settings, 2005. Vol. 54, MMWR Recomm Rep. 2005. $1 \mathrm{e} 141$.

9. United States of America. Centers for Disease Control and Prevention (CDC) - Healthcare Infection Control Practices Advisory Committee. Guidelines for Environmental Infection Control in Health-Care Facilities. US Dep Heal Hum Serv Centers Dis Control Prev Atlanta, GA 30329[Internet]. 2003;(2003):126-31.Available from: https://www.cdc.gov/ infectioncontrol/pdf/guidelines/env ironmental-guidelines.pdf\%0 Ahttps://www.cdc.gov/vhf/ebola/h ealthcare-us/hospitals/infectioncontrol.html\%0Ahttps://www.cdc.g ov/vhf/ebola/healthcareus/cleaning/hospitals.html\%0Ahtt ps://www.cdc.gov/vhf

10. Kementerian Kesehatan Republik Indonesia. Pedoman Teknis Prasarana Rumah Sakit Sistem Instalasi Tata Udara. 2012;

11. PT. Metcoindo Penta Perkasa. Laporan Pemeriksaan Pengujian Sistem Ventilasi dan Tata Udara Ruang isolasi RSPI Prof. Dr. 
Sulianti Saroso. 2017.

12. ASHRAE Handbook - Heating,

Ventilating, and Air Conditioning (HVAC) Applications. 2011;

13. Kementerian Kesehatan RI.

Direktorat Jenderal Pelayanan

Medik. Pedoman Operasional dan

Pemeliharaan Peralatan

Kesehatan. p. 2001. 